\title{
A FOREST VILLAGE ANALYSES FOR INTERVENING TO RURAL DEVELOPMENT: A CASE STUDY FROM TURKEY
}

\section{Uloga šuma u ruralnom razvoju: Studij slučaja šumskog sela iz Turske}

\author{
Ayhan $\mathrm{Akyol}^{1}$, Türkay Türkoğlu ${ }^{2}$, Ahmet Tolunay ${ }^{1}$, Adem $\mathrm{Efe}^{3}$
}

\begin{abstract}
This is a village case study, prepared by a research team, aimed at providing recommendations on sustainable rural development programs. The village of Yazır, located in the Ağlasun District of the Burdur Province, in the Western Mediterranean part of Turkey, was selected for abovementioned purpose. Rapid Rural Appraisal (RRA) and SWOT techniques were used as research tools for investigating rural conditions and gathering data from the village. The collected socio-economical and technical data were analyzed and discussed with the villagers to formulate a rural development project encompassing recommendations and activities.
\end{abstract}

Keywords: Sustainable Rural Development, Rapid Rural Appraisal technique, SWOT technique, village analyses, Yazır Village, Turkey.

\section{INTRODUCTION - Uvod}

Development is more closely associated with some form of action or intervention that can influence the entire process of social change. It is a dynamic concept, which suggests a change in, or a movement away from, previous situation (PRATT AND LOIZOS, 1992).

Rural development is a process integrated within the economic and social objectives, which must seek to transform rural society and provide a better and more secure livelihood for rural people (RAMBo, 1983). Rural development, therefore, is a process of analyzing the problem, identifying it and proposing relevant solutions (NICHOLS, 1991).This process is usually encompassed within a program or project which seeks to tackle the problem identified (OAKLEY AND GARFORD, 1987).

\footnotetext{
${ }^{1}$ Faculty of Forestry, Süleyman Demirel University, Eastern Campus, 32260 Isparta-TURKEY.

${ }^{2}$ Muğla Sitkı Koçman University, Köyceğiz Vocational School, Program of Forestry and Forest Products, 48800, Muğla-TURKEY.

${ }^{3}$ Faculty of Theology, SüleymanDemirel University, Eastern Campus, 32260 Isparta-TURKEY.
} 
Although Turkey is a developing country, it may be regarded as a developed country compared to other developing countries. However, as a developing country, rural development is still a very important issue for Turkey (TOLUNAY AND ALKAN, 2008).

This study attempts to study the socio-economical problem of a typical village and investigate the development process of rural conditions of Turkey, in addition to creating a village case study.

\section{MATERIALS AND METHODS - Materijali i metode}

The major method applied for this case study is Rapid Rural Appraisal (RRA), which is extensively used by a variety of social forestry projects focused on different rural resource issues in different parts of developing countries (CoNWAY, 1985). RRA is a study used as the starting point for understanding a local situation; carried out by a multidisciplinary team; lasting at least four days but not more than three weeks; and based on information collected in advance, direct observation and interviews where it is assumed that all relevant questions cannot be identified in advance (BEEBE, 1987). RRA is a more cost-effective and less time consuming way to investigate the management systems of rural resources. This form of research involves casual conversation with the villagers by an interdisciplinary team of researchers. Therefore, it provides opportunities for more interaction between the informants and researchers, enhancing better learning and conceptualization. Using the technique of semistructured interviewing, many questions can be constructed "on-the-spot”, offering flexibility to the existing situations (GRANDSTAFF AND GRANDSTAFF, 1987). The general RRA was applied in order to study the general features, socio-economic conditions and agriculture and land use pattern (APICHATVULLOP, 1987). The RRA technique includes: interviews, direct observations and secondary data analysis.

Interviews: Interviews were conducted by a team. The information was doublechecked, using the comparative approach (the same questions were addressed repeatedly to different inhabitants). Seven helpers, namely, How, Who, When, What, Where, Why, and If were also used. For individual interviews, households were selected by the team according to economic, gender and occupational criteria. Full interview pattern was used to obtain information.

Direct Observation: During the field study, the team directly observed the general conditions of the area, cropping pattern, home gardening, residences, fuel wood and forest products. The team also observed the present status of the forest and agricultural crops.

Secondary Data Analysis: Secondary data such as topographic maps, district and sub-district maps, rainfall, and temperature maps were analyzed. The data were obtained from several organizations in the Burdur Province.

Period of the Study: The team visited the village at different times. The first time, the visits were initiated in August and terminated in September 2013. This part of the study was designed to collect the data. The data collected comprised general information on the village and was obtained from the public offices in Ağlasun. 
During those visits, the village was monitored in order to compile a village profile and also observe the physical characteristics for drawing transects maps of the village. The second visit was conducted in order to collect the missing data and interviews were conducted with key respondent (headman, village members, teachers, etc.) in the village. These studies were performed in October-November 2013.

Main objectives of the research: The objectives of the study were as follows: (1) to study the cultural, physical and socio-economic conditions of the village, (2) to identify the needs and problems of the village, and (3) to recommend the most suitable solutions and proposals for the overall rural development of the village.

Household interviews were conducted focusing on the family structure, education, health, land use pattern, labor distribution, on farm and off-farm activities, income aspects, transportation etc. The second and third visits were designed to collect the missing data.

SWOT analysis was also utilized throughout the RRA study in order to identify the potential and restrictions of the village.

SWOT analysis: Comprising the internal and external status analysis of a country, region or institution, a SWOT analysis is based on the extensive investigation of a series of thoughts and internal and external factors constituting the subject matter of the analysis. These internal and external factors are categorized into four groups, namely, strengths, weaknesses, opportunities and threats. This enables the achievement of an optimum balance between internal and external factors throughout the planning process. Furthermore, SWOT analyses are also used for considering, comparing alternative decisions and selecting the most suitable decision at the end (YILMAZ, 2007).

The studies conducted by KuRTtilaet AL., (2000), Shrestha ET AL., (2004), TÜRKERAND YENI (2006), and TOKSOYET AL., (2009) may be taken as example with regard to SWOT analyses which have become more diffused in recent years.

\section{DESCRIPTION OF THE VILLAGE - Opis sela}

\section{Physical setting - Fizičke postavke}

Location: The Yazır Village is located in the north eastern part of Ağlasun District of the Burdur Province. It is 5 kilometers away from the Ağlasun District. It is approximately 36 and 38 kilometers away from Burdur and Isparta Provinces, respectively. There are two Villages that belong to Yazır. One of them is theSakarlar Village, while another one is the main Village, i.e. the Yazır Village. Sakarlar Village is 3 kilometers away from the Yazır Village. There is another road that extends to theSakarlar Villageat the eastern part of the village without any passage through the main Village. This road reaches the Ağlasun-Isparta main road by 4 kilometers. The village is very close to the state forest in the north eastern region and the new afforestation at the north western and western regions. The Yazır Village surrounds 
the Dereköy village in the southeast, the Ağlasun District in the west, theDirekli Village in the north of the Isparta Province and the Kadilar Village in the northeast of the Isparta Province.

Climate: The Yazır Village has a Mediterranean climate, in which the summers are hot and dry and winters are warm and wet. The average annual rainfall is $436.7 \mathrm{~mm}$ (Table 1). There are four distinct seasons in this village, namely, spring from March to May is followed by the summer season, ranging from June to August; then the autumn season ranging from September to November and lastly winter starts in December and terminates at the end of February. The average annual temperature is $13.2^{\circ} \mathrm{C}$.

Topography: The study area lies at the skirts of the Akdağ Mountain where there are harsh natural conditions. There is no vegetation at its peak as well as its lower parts $(2271 \mathrm{~m})$. Coming down from the peak of the Akdağ Mountain towards the settlement area of the Yazır Village, the land undulates and gentle slopes to the southern part of the village, passing through the Ağlasun-Isparta main road. The gentle slope areas range from $5 \%$ to $35 \%$, with very little steep slopes exceeding $35 \%$.

Table 1. Monthly rainfall distribution in the Ağlasun District Tabela 1. Mjesečna distribucija oborina u A ğlasun distriktu

\begin{tabular}{ccccccccccccc}
\hline Months & $\begin{array}{c}\text { Jan } \\
\text { Mm }\end{array}$ & $\begin{array}{c}\text { Feb } \\
\mathrm{mm}\end{array}$ & $\begin{array}{c}\text { March } \\
\mathrm{Mm}\end{array}$ & $\begin{array}{c}\text { April } \\
\mathrm{mm}\end{array}$ & $\begin{array}{c}\text { May } \\
\mathrm{mm}\end{array}$ & $\begin{array}{c}\text { Jun } \\
\mathrm{mm}\end{array}$ & $\begin{array}{c}\text { July } \\
\mathrm{mm}\end{array}$ & $\begin{array}{c}\text { Aug } \\
\mathrm{mm}\end{array}$ & $\begin{array}{c}\text { Sep } \\
\mathrm{mm}\end{array}$ & $\begin{array}{c}\text { Oct } \\
\mathrm{mm}\end{array}$ & $\begin{array}{c}\text { Nov } \\
\mathrm{Mm}\end{array}$ & $\begin{array}{c}\text { Dec } \\
\mathrm{mm}\end{array}$ \\
\hline Rainfall & 62.6 & 45.2 & 45.3 & 37.0 & 48.9 & 25.5 & 8.6 & 5.9 & 17.1 & 30.0 & 35.5 & 75.2 \\
\hline
\end{tabular}

Soil: Soil types can be classified as sandy clay loam, sandy loam and clay loam soils mixed with tiny stones and having a low fertility and low moisture holding capacity. Due to the topography, run-off is very common in heavy rain. Thus, the level of nutrients in the topsoil is very low because of erosion.

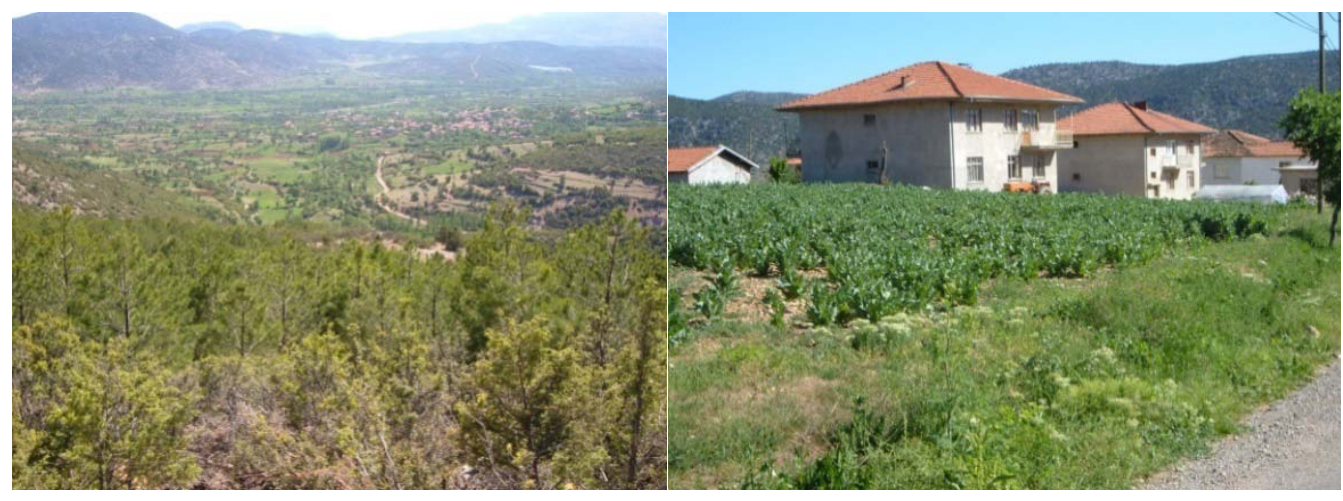

Photos 1 and 2: A view of the Yazir Village

Fotografije 1 i 2: Pogled na Yazır selo 
Water Resources: The major sources of water in this village derive from spring, river and ground water. The villagers use water from different sources for different purposes, such as springs for drinking. There is a water depot and water network in the village. Each household is subscribed to the water utilization system. The Ağlasun River is right next to the village. It is a water resource utilized for agricultural purposes. However, the river does not have enough water to be used for irrigation in summer. The source of the Ağlasun River is in Yeşilbaşköyand it flows from that point towards the settlement area in the east. It passes through the settlement of Ağlasun and reachesDereköy which is the neigh boring village of Yazır. In summer, everyone involved in agricultural work in Ağlasun and Yeşilbaşköy need more irrigation water. They use all the water in the river for their lands. Thus, the villagers of Yazır do not take water for agricultural purpose. Villagers solved this problem by using ground water wells. There are 6 water wells in the village. Four wells belong to State Hydraulic Works (DSI), while two well are made by the village autonomously. One of the water wells had broken down during the time when the interviews were made. Other water resources for irrigation are springs that derive from the Akdağ Mountain. The Somakl1 Plateau is the main resource of springs. Villagers transport the water from these springs to their lands via water canals. On the other hand, the location next to the Kilıçlı Side (at a level of $1.500 \mathrm{~m}$ ) provides water resources for springs. These springs are used for livestock.

Vegetation: One thousand years ago, the village area was covered with forest. However, due to the influx of settlers and rapid destruction of the forest through shifting cultivation, only few scattered natural trees are found on the farm land. The main tree species are; Juniper spp., Turkish pine (Pinus brutia Ten.), Crimean pine (Pinusnigra Arnold.), Lebanon cedar (Cedrus libani, A. Rich.) and some oak species especially Quercus coccifera L., umbrella pine (Pinus pinea L.), ash (Fraxinus spp), willow (Salix spp.), poplar (Populus spp.) and nettle tree (Celtis spp.). As the state forests next to the village werein an unproductive status, forestations were made by the Ministry of Forestry and the State Hydraulic Works Agency. The work was initiated in 1984 and terminated in 1986. The selected species isthe Crimean pine (Pinus nigra, Arnold). If the village settlement area and agricultural fields are considered from a vegetation perspective, it should be stated that almost every household has planted trees around their homestead. Some households have planted fruit orchards with figs, pomegranates, walnuts, white mulberries, plums, pears and apples.In the settlement of the Yazır village, where the majority of the population is composed of farmers, the original vegetation was greatly modified due to farming activities.

\section{Socioeconomic and cultural setting - Socioekonomsko i kulturno okruženje}

Demographic characteristics: The villagers settled in the village at beginning of 1900 's, and also migrated from the Gerce Village close to the Bucak District which is in Burdur Province. The people that first settled there during that period came to this 
region in order to find haystack. Presently, the village is composed of two Villages, namely Yazır and Sakarlar.

The total number of households in the village is approximately 225, with a total population of about 950 people. Twenty-five households are empty with no people living in them. The average number of persons per household is four. The Sakarlar Village has 9 households with a population of 20 people.

Education: There is a primary school in the village, which has 70 pupils and a staff of 6 teachers. There is also a primary school in the Sakarlar Village, but it is closed, now. There are six classes in the school of the Yazır Village and one of them is a pre-school education class. Others are normal primary school classes. Turkey switched to compulsory 8-year primary education in 1997. When a student completes five years of education, he/she has to continue with compulsory education in another school within theAğlasun District. There are 40 students who pursue their education in Ağlasun. About $99 \%$ of the villagers are literate.

Religion and belief system: All of the inhabitants of the village are Muslim. No other religion is known to exist in this area. There is a mosque located in the Yazir Village, with one imam. The function of the imam is to perform religious services and prayers and also to solve religious problems in the village. There is one mosque in the Sakarlar Village, as well. It is closed and thus does not have an imam now.

Health and nutrition: There is no public health clinic in the Yazır Village. If somebody is severely sick, he/she is taken to a health clinic located inAğlasun or to a provincial hospital (in Burdur or Isparta) to receive proper care. Villagers also use local medicinal plants for therapeutic purposes. Healthcare officials from the Ağlasun health clinic visit the village regularly in order to promote vaccination programs and family planning. The common diseases which are seen in the village are cold and fever.

Occupation: Most villagers are farmers and most of them cultivate their own farmland. About $20 \%$ of the villagers work as hired workers outside the village, because they have a small farm or only a homestead. However, some farmers who have their own farm also work as laborers in other farms in order to gain extra income. The average labor wage in the Yazır village is $20 \mathrm{TL}$ per person/day.

Most young adults (16-30 years) who have no or little land have moved to urban areas in order to find jobs because the wages are nearly double the amount in the village. Fifty young people from the village found a job in a firm named Kadıahmetoğulları in Antalya. This firm produces concrete and asphalt materials. Reciprocal labor during busy times is also commonly practiced by some of the villagers. A few farmers are involved in apiculture and produce honey in the Sakarlar Village. On the other hand, there are 5 carpet-weaving units in the village. Carpets are sold in the Isparta Province.

Village administration: The village is led by the village headman. The administration structure is further strengthened by 5 members of the village committee. The headman and the village committee members are elected by the villagers and solve all the problems of the village (except for serious crimes). 
Trade: The main food in the village is composed of bread, vegetables, meat, fruits, and fish. There are 5 shops in the village where villagers can buy commodities. Maize, grain and beetroot are the major agricultural commodities. The villagers sell their produce directly to the markets in the Ağlasun, Isparta and Burdur Provinces.

Infrastructure: Most of the houses are made of bricks. There are some houses built with sun-dried bricks some time ago. Electricity is available in the village. Some households are using it for cooking and heating. Villagers are also using solar energy for heating water. There are 80 houses with sun panel in the village. A water depot and a water network should be added to the infrastructure. There are two graveyards in the village. Postal and telecommunication services are available. There are some fixed line telephones, but almost everyone (especially the younger population) uses mobile telephones. Postal communication is supplied by village headmen.

Pick-ups, tractors, cars, motorcycles, bicycles and midi buses are common modes of transportation. The number of midi buses, tractors, lorries and cars is 1, 50, 4 and 20, respectively. Villagers can go to the Ağlasun market with a hired midi bus each Friday. An asphalt road runs through the village towards the Ağlasun District.

There are is a TV set, radio and refrigerator in all households. Half of the households havea washing machine and a dishwasher. There are 5 shops, 4 coffeehouses and 1 barbershop in the village. All of them are located in the main Villageof Yazır. There is a simple irrigation system in the YazırVillage. The road that extends to the Sakarlar Village from the main Village is sandy and with no asphalt surface. In winter, the road can be closed down due to torrents and floods.

Income: As mentioned earlier, the majority of villagers are farmers, so their economy is mainly based on agricultural products. Maize, grain, beetroot, rose garden and poppy (in small amount) constitute the major cash crops in this village. Fruit orchards and livestock farming are other sources of income. Apart from the sale of agriculture products, labor is also another source of income for villagers both inside and outside the village. Many young men have moved to cities to earn extra income due to higher wages in cities. The average wage in the village is $20 \mathrm{TL}$, whereas it is double this amount in cities (such as Isparta or Antalya) it is about the double the village rate.

\section{AGRICULTURE AND LAND USE PATTERN - Poljoprivreda i obrasci korištenja zemljišta}

The utilization structure of the Ağlasun District, based on its agricultural records, is provided in Table 2. The total land of the village amounts to 22.446 decares, with 3.283 decares of composed of agricultural land, 13.700 decares forest areaand 5.463 decares of infertile land. 
Table 2. Land using structure in Yazır Village

Tabela 2. Struktura korištenja zemljišta u selu Yazir

\begin{tabular}{cccc}
\hline $\begin{array}{c}\text { Agricultural land } \\
\text { Decares }\end{array}$ & $\begin{array}{c}\text { Infertile land } \\
\text { Decares }\end{array}$ & $\begin{array}{c}\text { Forest area } \\
\text { Decares }\end{array}$ & $\begin{array}{c}\text { Total land } \\
\text { Decares }\end{array}$ \\
\hline 3.283 & 5.463 & 13.700 & 22.446 \\
\hline
\end{tabular}

Source: Agricultural Department of Ağlasun, 2013

\section{Cropping pattern - Način obrade}

Out of the total area composed of approximately 3300 decares, excluding homesteads or home garden areas, all land is suitable for growing agricultural products i.e. maize, grain, beetroot and other species. The cropping pattern in the Yazır Village is presented in Table 3. Maize for livestock feeding is an important crop in the area. Only a few villagers grow beetroot. Maize can be planted two times a year, but most of the villagers grow it only once between April and August. The farmers usually plant their crops between April and May. Each crop is mostly grown once a year.

Chemical fertilizers are used for growing agricultural products and most of the farmers use pesticides for weed control. Most of the middle and low income household perform weeding and harvesting. Fruit trees are observed throughout the village in both home gardens and small orchards. Intercropping of maize and agro forestry practices (e.g. fruit trees and crops like maize and vegetables, etc.) in the alley cropping model is also found in the village. In terms of yield, as noted in the soil section, farmers have noticed that it has been declining over time. Factors such as low rainfall, continuous cropping, choice of crop, machinery, low soil fertility and soil erosion are the main causes of the current declining productivity of their farmlands.

Table 3. Land utilization structure in the Yazir village

Tabela 3. Struktura korištenja zemljišta u selu Yazir

\begin{tabular}{cccccc}
\hline $\begin{array}{c}\text { Irrigated } \\
\text { farming areas } \\
\text { Decares }\end{array}$ & $\begin{array}{c}\text { Dry farming } \\
\text { areas } \\
\text { Decares }\end{array}$ & $\begin{array}{c}\text { Vegetables areas } \\
\text { Decares }\end{array}$ & $\begin{array}{c}\text { Orchards } \\
\text { Decares }\end{array}$ & $\begin{array}{c}\text { Poplar } \\
\text { plantation } \\
\text { Decares }\end{array}$ & $\begin{array}{c}\text { Total lands } \\
\text { Decares }\end{array}$ \\
\hline 1.669 & 1.285 & 98 & 213 & 18 & 3.283 \\
\hline
\end{tabular}

Source: Department of Agriculture ofAğlasun, 2013

\section{Farm size and land tenure - Veličina posjeda i zakupa zemljišta}

For the first settlers there was no limit in land holding size. But, now landholding size is limited. There is a lot of variation in terms of farm sizes in the village. Table 4 and Table 5 demonstrate different farm sizes according to total agricultural lands and the households in terms of ownership of agricultural land. According to landholding, villagers can be categorized into 2 groups:

1. Landholders - about 90 percent of households,

2. Landless - about $10 \%$, with a small piece of land to support them 
Table 4. Farm size in total agricultural lands

Tabela 4. Veličina poljoprivrednog posjeda u ukupnom poljoprivrednom zemljištu

\begin{tabular}{ccccccc}
\hline $\begin{array}{c}\text { 0- } \\
\text { 5Decares }\end{array}$ & $\begin{array}{c}\text { 6- } \\
\text { 10Decares }\end{array}$ & $\begin{array}{c}\text { 11- } \\
\text { 20Decares }\end{array}$ & $\begin{array}{c}\text { 21- } \\
\text { 50Decares }\end{array}$ & $\begin{array}{c}\text { 51- } \\
\text { 100Decares }\end{array}$ & $\begin{array}{c}\text { 101- } \\
\text { 200Decares }\end{array}$ & TotalDecares \\
\hline 127 & 419 & 1.088 & 1.462 & 187 & - & 3.283 \\
\hline
\end{tabular}

Table 5. Size of farms owned by households

Tabela 5. Veličina poljoprivrednog posjeda u vlasništvu kućanstava

\begin{tabular}{ccccccc}
\hline $\begin{array}{c}\text { 0- } \\
\text { 5Decares }\end{array}$ & $\begin{array}{c}\mathbf{6 - 1 0} \\
\text { Decares }\end{array}$ & $\begin{array}{c}\text { 11- } \\
\text { 20Decares }\end{array}$ & $\begin{array}{c}\text { 21- } \\
\text { 50Decares }\end{array}$ & $\begin{array}{c}\mathbf{5 1 - 1 0 0} \\
\text { Decares }\end{array}$ & $\begin{array}{c}\mathbf{1 0 1} \text {-200 } \\
\text { Decares }\end{array}$ & TotalDecares \\
\hline $\begin{array}{c}44 \\
\text { households }\end{array}$ & $\begin{array}{c}47 \\
\text { households }\end{array}$ & $\begin{array}{c}66 \\
\text { households }\end{array}$ & $\begin{array}{c}45 \\
\text { households }\end{array}$ & $\begin{array}{c}3 \\
\text { households }\end{array}$ & - & $\begin{array}{c}205 \\
\text { households }\end{array}$ \\
\hline
\end{tabular}

\section{Livestock - Stočni fond}

Most of the households have livestock such as cows, domestic goats and sheep. There are also chicken in almost all households. Cows are raised for milk to earn income. There are 400 cows, 2.000 domestic goat sand 100 sheep in the Yazır Village. On the other hand, the Sakarlar Village has 500 domestic goats, 100 sheep and 15 cows. The village has no communal grazing area and livestock are grazed on fallow land and stalls are fed by cutting grass. Some farmers allocate land for growing grass and for grazing.

\section{UTILIZATION OF FORESTS AND TREES - Korištenje šume i drveća}

\section{Tree growing pattern - Sadnja drveća}

Villagers have an awareness and strong perception about the importance of forests and trees. Some of the state forests adjacent to the village are in an unproductive status. When the forestry administration came to the village for forestation in 1984, the villagers did not protest the government officers. Although the land with plantation was used as a pasture for livestock, they accepted forestation in the northern part of village. Forestation was initiated in 1984 and completed in 1986. The species that were planted were the Turkish pine (Pinus brutia Ten.) and Crimean pine (Pinus nigra Arnold.). The trees that were planted in the plantation areas gradually grew, reaching a height of 2-4 meters. The forest administration gave permission to the villagers herd their sheep in forests. Currently, new studies are conducted with regard to grazing in Turkey and various approaches are displayed especially on goat grazing (TOLUNAYET AL., 2009). 


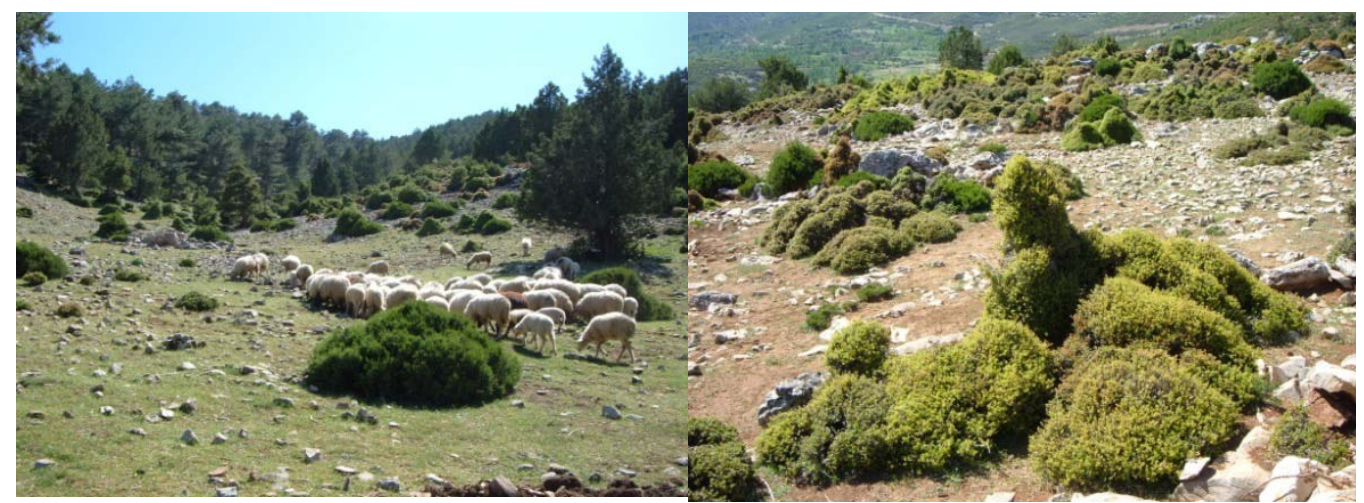

Photos 3 and 4. Intense grazing and its results at the Yazır Village

Fotografije 3 i 4. Instenzivna ispaša i njen rezultat u selu Yazir

On the other hand, most of the villagers grow trees on the border of their fields or in line with an agro forestry system (orchard or mixed fruit trees with agricultural crops). The common tree species which they have planted are: figs (Ficus spp. L.), pomegranates (Punica granatum L.), walnuts (Juglans regia L.) white mulberries (Morus alba L.), plums (Prunus myrobolana Leisel), pears (Pirus communis L.) and apples (Malus spp.) Villagers reported that they would to grow cherries, but the germination of this species is not possible in village conditions.Some villagers also grow trees along the border of their homestead for boundary demarcation.

\section{Forest areas and products - Šumska područja i šumski proizvodi}

There are 13.700 haof forest areas within the village. All forests belong to the government. Timber, poles, wood for making charcoal and fuel wood are important products. Some villagers use trees also as medicinal plants, collecting plants in their home gardens as well as from nearby forests. In Turkey, forest villagers have some utilization rights according to Law No. 6831. According to such rights, construction materials and fuel wood should be given to forest villagers at reduced prices. Forest villagers in the Yazır village are supplied with construction materials from the Directorate of Forestry Department of Ağlasun. Fuel wood is also given to the villagers. Nowadays, villagers are gathering the waste material from the forests. Table 6demonstrates the amount of the construction material supplied to the village.

There are also studies conducted on the utilization of forestry products (TOLUNAYET AL., 2008) and home garden applications (BAŞSÜLLÜ AND TOLUNAY, 2010) in the region. 
Table 6.Construction materials obtained taken from the Directorate of Forestry Department of Ağlasun Tabela 6. Dobiveni građevinski materijali preuzeti iz Uprave za šumarstvo u Ağlasun-u

\begin{tabular}{cccccccccccc}
\hline $\begin{array}{c}\text { Before 1994 } \\
\mathrm{m}^{3}\end{array}$ & $\begin{array}{c}1994 \\
\mathrm{~m}^{3}\end{array}$ & $\begin{array}{c}1995 \\
\mathrm{~m}^{3}\end{array}$ & $\begin{array}{c}1996 \\
\mathrm{~m}^{3}\end{array}$ & $\begin{array}{c}1997 \\
\mathrm{~m}^{3}\end{array}$ & $\begin{array}{c}1998 \\
\mathrm{~m}^{3}\end{array}$ & $\begin{array}{c}1999 \\
\mathrm{~m}^{3}\end{array}$ & $\begin{array}{c}2000 \\
\mathrm{~m}^{3}\end{array}$ & $\begin{array}{c}2001 \\
\mathrm{~m}^{3}\end{array}$ & $\begin{array}{c}2002 \\
\mathrm{~m}^{3}\end{array}$ & $\begin{array}{c}2003 \\
\mathrm{~m}^{3}\end{array}$ & $\begin{array}{c}\mathbf{2 0 0 4} \\
\mathrm{m}^{3}\end{array}$ \\
\hline 2.191 & 77 & 135 & 42 & 56 & 50 & 34 & 36 & 40 & 108 & 94 & 45 \\
\hline
\end{tabular}

\section{SOURCES AND USE OF ENERGY - Izvori i korištenje energije}

Wood: Most of the house holds use fuel wood for heating in the Yazir Village. A few of the households use fuel wood for cooking. Some fuel wood is supplied to the villagers by the Department of Forestry of Ağlasun. Because, each household in the village has the right for fuel wood right, according to the Turkish Forestry Law (Articles 31, 32).Some records from the Department of Forestry of Ağlasundated 1984-2004 are provided in Table 7.

Table 7. Fuel woods upplied by the department of forestry villagers within 20 years

Tabela 7. Ogrjevno drvo obezbijeđeno od strane Odjela za sela uz šumu unutar 20 godina

\begin{tabular}{lcccccccccc}
\hline Years & $\begin{array}{c}\mathbf{1 9 8 4} \\
\text { Ster }\end{array}$ & $\begin{array}{c}\mathbf{1 9 8 5} \\
\text { Ster }\end{array}$ & $\begin{array}{c}\mathbf{1 9 8 6} \\
\text { Ster }\end{array}$ & $\begin{array}{c}\mathbf{1 9 8 7} \\
\text { Ster }\end{array}$ & $\begin{array}{c}\mathbf{1 9 8 8} \\
\text { Ster }\end{array}$ & $\begin{array}{c}\mathbf{1 9 8 9} \\
\text { Ster }\end{array}$ & $\begin{array}{c}\mathbf{1 9 9 0} \\
\text { Ster }\end{array}$ & $\begin{array}{c}\mathbf{1 9 9 1} \\
\text { Ster }\end{array}$ & $\begin{array}{c}\mathbf{1 9 9 2} \\
\text { Ster }\end{array}$ & $\begin{array}{c}\mathbf{1 9 9 3} \\
\text { Ster }\end{array}$ \\
\hline Amount & 1.110 & 1.120 & 1.140 & No record & No record & $\begin{array}{c}\text { No } \\
\text { record }\end{array}$ & 350 & 291 & 151 & $\begin{array}{c}\text { No } \\
\text { record }\end{array}$ \\
\hline \multicolumn{2}{l}{ Continued } & & & & & & & & & \\
\hline $\mathbf{1 9 9 4}$ & $\mathbf{1 9 9 5}$ & $\mathbf{1 9 9 6}$ & $\mathbf{1 9 9 7}$ & $\mathbf{1 9 9 8}$ & $\mathbf{1 9 9 9}$ & $\mathbf{2 0 0 0}$ & $\mathbf{2 0 0 1}$ & $\mathbf{2 0 0 2}$ & $\mathbf{2 0 0 3}$ & $\mathbf{2 0 0 4}$ \\
Ster & Ster & Ster & Ster & Ster & Ster & Ster & Ster & Ster & Ster & Ster \\
\hline 260 & 588 & 336 & 783 & No record & 114 & No record & 200 & $\begin{array}{c}\text { No } \\
\text { record }\end{array}$ & No record & 101 \\
\hline
\end{tabular}

Note: 1 ster is 200-250 kg. in softwood and 400-450 kg. in hardwood.

A careful assessment of these records clearly shows that villagers are getting fuel wood in a decreasing trend. In fact, this is exactly true. Because, in 1980's fuel wood was supplied to the villagers at low prices. But, nowadays people have to get their fuel wood at real prices (real market prices). For this reason, people in the village are searching for different fuel wood resources. According to the villagers, dead and fallen trees on the farm land are another source of fuel wood. It was also detected that many of the households use branches of trees from home garden trees for fuel wood. Villagers mentioned that dead and fallen trees on farmland are very scarce now, so some people, mostly the poor, go to the forest to collect dead and fallen wood, but they do not cut the living trees. Due to the scarcity of wood, people are now uprooting the stumps of old trees to overcome the deficit of fuel wood.

Non-wood: All of the settlement groups in the village have already been mentioned in the section on infrastructure chapter. All villagers have electricity and households use electricity as a source of energy for cooking. On the other hand, some 
of the middle income and rich families also use gas. Villagers are also using solar energy for heating water. There are 80 households with sun panels in the village.

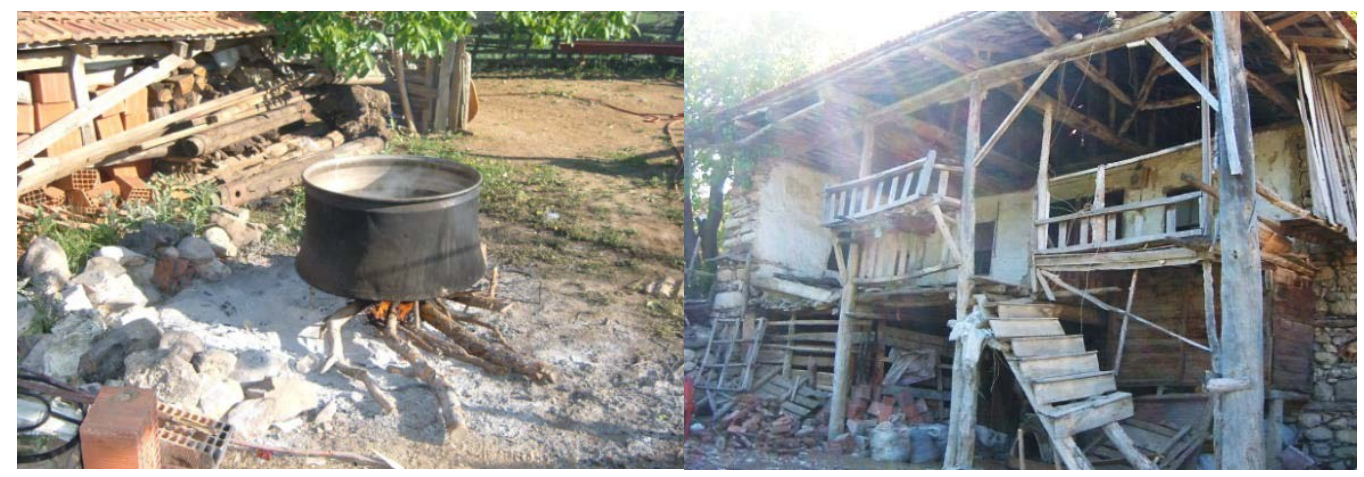

Photos 5 and 6. Different uses of wood

Fotografije 5 i 6 . Različiti načini upotrebe drveta

\section{SWOT ANALYSIS - SWOT analiza}

In this study, also the assessments comprising the strengths, weaknesses, opportunities and threats were included in addition to the RRA technique in order to identify the socio-economic structure of the Yazır Village. It was aimed to reveal the key factors impacting the socio-economic structure of the village with the SWOT analysis (Table 8).

Table 8. Assessments relating to the SWOT analysis

Tabela 8. Procjene koje se odnose na SWOT analizu

\begin{tabular}{|c|c|}
\hline $\begin{array}{l}\text { Strengths } \\
\text { - Rich regional culture } \\
\text { - Presence of archaeological areas (ancient city } \\
\text { of Sagalassos) } \\
\text { - Presence of areas suitable for rural tourism } \\
\text { practices } \\
\text { - Proximity to the market and shopping areas } \\
\text { (Antalya, Isparta, Burdur) }\end{array}$ & $\begin{array}{l}\text { Weaknesses } \\
\text { - Lack of infrastructure in the village } \\
\text { - Small scale animal and agricultural } \\
\text { production; production performed for } \\
\text { consumption } \\
\text { - Insufficient labor force, low rate of young } \\
\text { population, high rate of old people in the } \\
\text { population } \\
\text { - Insufficient financial resources } \\
\text { - Sloped and infertile land structure }\end{array}$ \\
\hline $\begin{array}{l}\text { Opportunities } \\
\text { - Subsidies for fulfilling EU obligations } \\
\text { - Expanding the market introduction of value } \\
\text { added products (organic farming) } \\
\text { - Availability of a diversity suitable for } \\
\text { performing different recreational and touristic } \\
\text { activities } \\
\text { - Expanding alternative touristic activities } \\
\text { affiliated with natural and cultural resources }\end{array}$ & $\begin{array}{l}\text { Threats } \\
\text { - Migration from the village to cities } \\
\text { - Low demand for recreational activities } \\
\text { - Economic challenges } \\
\text { - Illegal and uncontrolled utilization of forest } \\
\text { resources } \\
\text { - Visual pollution generated by various } \\
\text { economic activities (marble and stone } \\
\text { quarries) }\end{array}$ \\
\hline
\end{tabular}




\section{CONCLUSION - Zaključci}

Various socioeconomic and environmental problems were identified in the study on the Yazir village. As some of these problems have become a constraint, the villagers are considering alternatives for overcoming these problems.

(1) Lack of water: Water is scarce during summer for farming. Water supply for farming always constitutes a problem in the summer season. Since there is no proper irrigation system, the water distribution leads to poor crop production.

(2) Decline in land productivity: A major cause of farmers' soil degradation is the "Up-down slope" style mechanical ploughing. It is a common practice applied throughout the village and a major cause of soil erosion, thus decreasing soil fertility.

(3) Lack of income generating activities: Generally, there is a lack of income generating activities to supplement the relatively poor farm production. This results in the migration of young people to cities in order to find employment for the villagers.

(4) Shortage of fuelwood and timber: One hundred years ago, the village area was covered with dense vegetation of trees on farmlands. Previously, the forest provided the villagers with abundant fuelwood and construction timber, but this has been greatly reduced now. The Forest Administration has taken serious steps in order to stop illegal felling; the villagers noticed that the supply of fuelwood as well as construction timber has decreased significantly.

(5) Extensive exploitation of underground and surface resources: there are numerous quarries for construction materials (mainly marble and granite), due to the real estate boom, which gravely affects the entire landscape. This threat is not directly connected only to the Yazır area, but to the entire region. An aggravating feature lies in the substantially rapid progress that characterizes these exploitations. In order to preserve natural richness and biodiversity, measures have to be enforced before it is too late.

Considering the fact that Yazır is a very small village, located in a remote area, with very few resources, its inhabitants are forced to cope with many economical, infrastructural and social challenges. In order to identify effective solutions for their main problems, detailed documentation needed to be compiled. Therefore, this research focused on recording the general situation of this village, covering most of the aspects related to the everyday life of its settlers. The relevance of this new database lies in the fact that there were almost no previous studies regarding Yazır.

\section{REFERENCES - Literatura}

AAD, (2013): Ağlasun Agricultural Department.Avaiable at:http://www.burdurtarim.gov.tr/

ApichatVulloP, Y. (1992): Rapid Rural Appraisal for Community Forestry, Lecture for Regional Training Course in Community Forestry Development Techniques (Jan. 20-Feb. 28, RFD), Bangkok, Thailand. 
BAŞSÜLLÜ, Ç., TolunAY, A. (2010): General Characteristics of Traditional Homegarden Involving Animal Practices in Rural Areas of Isparta Region of Turkey, Journal of Animal and Veterinary Advances, 9 (3): 455-465.

BeEbe, J. (1987): Rapid Appraisal: The Evaluation of the Concepts and the Definition of Issues, (A Lecture for Proceedings of the 1985 International Conference on Rapid Rural Appraisal), KhonKaen University, Thailand.

ConwAY, G. (1985): Rapid Rural Appraisal and Agro-ecosystem Analysis: A Case Study from Northern Pakistan, (A Lecture for Proceedings of the 1985 International Conference on Rapid Rural Appraisal), KhonKaen University, Thailand.

GRANDSTAFF, W.S., GRANDStAFF, T.B. (1987): Semi-structured Interviewing by Multidisciplinary Team in RRA (A Lecture for Proceedings of the 1985 International Conference on Rapid Rural Appraisal), KhonKaen University, Thailand.

Kurttila, M., Pesonen, M., Kangas, J., Kajanus, M. (2000): Utilizing the analytic hierarchy process AHP in SWOT analysis - a hybrid method and its application to a forest-certification case, Forest Policy and Economics, 1: 41-52.

NicHols, P. (1991): Social Surveys Methods (A Fieldguide for Development Workers), Development Guidelines, No: 6, (Edited by B. Pratt), Oxfam, 274 Banbury Road, Oxford, England.

OAKLEY, P., GaRForth, C. (1985): Guide to extension training, FAO Training Series, No: 11, FAO, Rome, Italy

Pratt, B., Loizos, P. (1992): Choosing Research Methods (Data Collection for Development Workers), Development Guidelines, No: 7, Oxfam, 274 Banbury Road, England.

RamBo, A.T. (1983): Conceptual Approaches to Human Ecology, East-West Environment and Policy Institute, Research Report No: 14, Honolulu, Hawaii, USA.

Shrestha, R.K., Alavalapati, J.R.R., Kalmbacher, R.S. (2004): Exploring the potential for silvopasture adoption in south-central Florida: an application of SWOT-AHP method. Agricultural Systems, 81: 185-199.

ToKsoY, D., YeNIGÜN, M., ŞEN, G. (2009): Evaluation of agricultural development cooperatives in the forest villages by SWOT analysis (the case study in Mac, ka).KastamonuUniversity, Journal of Forestry Faculty, 9 (1): 12-18.

Tolunay, A., AyHAN, V., INCE, D., Akyol, A. (2009): Traditional usage of kermes oak (Quercuscoccifera L.) and pure hair goat (Capra hircus L.) in a silvopastoral system on Davras Mountain in Anatolia: Constraints, problems and possibilities. Journal Animal and Veterinary Advances, 8 (8): 1520-1526.

Tolunay, A., Alkan, H. (2008): Intervention to the misuse of land by the forest villages: A case study from Turkey, Ecology 17-68:1-10. 
Tolunay, A., AKYol, A., ÖZCan, M. (2008): Usage of trees and forest resources at household level: A case study of AşağıYumrutaş Village from the West Mediterranean Region of Turkey. Research Journal of Forestry, 2-1: 1-14.

TÜRKER, M.F., YENI, F.A. (2006): Using SWOT Analysis in public forest enterprises to achieve management objectives: Maçka State Forest Enterprise case in Turkey.

SOCIO-ECONOMIC ISSUES CONGRESS IN FORESTRY, Ankara University, Çankırı Forest Faculty, pp. 297-303.

YILMAZ, E. (2007):Participatory Project Assessment Using a SWOT Method, Eastern Mediterranean Forestry Research Institute, DOA Journal, 13: 1-16.

\section{Sažetak}

Ovo istraživanje predstavlja studij slučaja za naselje Selo Yazır. Istraživanje je pripremljeno od strane istraživačkog tima, s ciljem pružanja preporuka za održive programe ruralnog razvoja. Selo Yazır, nalazi se u Ağlasun okrugu, Provincija Burdur, u zapadno-mediteranskom dijelu Turske. Kao istraživački alati za istraživanje ruralnih uvjeta i prikupljanje podataka iz sela korišteni su: Rapid Rural Appraisal (RRA) i SWOT tehnike. Prikupljeni socio-ekonomski i tehnički podaci su analizirani sa mještanima, što je pomoglo u formuliranju projekta ruralnog razvoja koji obuhvaća preporuke i aktivnosti koje su prizišle iz navedenih aktivnosti. 